\title{
The role of tumor necrosis factor-receptors in pregnancy with normal and adverse outcome
}

This article was published in the following Dove Press journal:

International Journal of Interferon, Cytokine and Mediator Research

I February 2012

Number of times this article has been viewed

\author{
Jean Calleja-Agius' \\ Shanthi Muttukrishna ${ }^{2}$ \\ Eric Jauniaux' \\ 'Academic Department of Obstetrics \\ and Gynaecology, University College \\ London Institute for Women's \\ Health, WCIE 6HX London, United \\ Kingdom; ${ }^{2}$ Anu Research Centre, \\ University College Cork, Department \\ of Obstetrics and Gynaecology, Fifth \\ Floor, Cork University Maternity \\ Hospital, Wilton, Cork, Republic \\ of Ireland
}

\begin{abstract}
TNF $\alpha$ receptors, TNF-R1 and TNF-R2, mediate the biological activities of the multifunctional cytokine, tumor necrosis factor alpha, TNF $\alpha$. These receptors have a central role in human pregnancy. Although each receptor induces distinct intracellular signals, they also have co-operative and overlapping effects. The membrane bound TNF-R1 carries out most of the pro-inflammatory activities of TNF $\alpha$, especially those that are rapid, while TNF-R2 is involved in the late long-term effects of this cytokine. The soluble forms of these receptors can bind to TNF $\alpha$, neutralizing its effects. In normal human pregnancy, TNF $\alpha$ receptors are present in the maternal circulation, placenta, amniotic fluid, and coelomic cavity. Changes in $\mathrm{TNF} \alpha$ and its receptors are associated with adverse pregnancy outcomes, including miscarriage, preterm labor and preeclampsia. Advances in anti-TNF $\alpha$ therapy may have potential use in the management of complicated pregnancies.
\end{abstract}

Keywords: TNF $\alpha$ receptors, pregnancy, miscarriage, preeclampsia, preterm labor

\section{Introduction}

The role of maternal leucocytes and other immune factors such as cytokines in the trophoblast-decidual interaction remains unclear. There are two major subsets of CD4+ T-helper mediated responses, T-helper Th1 and Th2, ${ }^{1}$ which act via different patterns of cytokine production. Th1 cells secrete tumor necrosis factor (TNF) $\alpha$ and $\beta$, interferon gamma (IFN $\gamma$ ) and interleukin (IL)-2. This cell-mediated immune response, also known as Type 1 response, involves activation of macrophages and cell-mediated reactions involved in resisting infections due to intracellular pathogens, and cytotoxic and delayed-type hypersensitivity reactions. Th2 type cytokines include IL-4, IL-5, IL-6, IL-10, and IL-13, which are associated with strong antibody responses to infections with extracellular organisms (Type 2 or humoral reactions). ${ }^{2}$ There is evidence that cytokines are pivotal in the reproductive immune response..$^{3-6}$ Normal pregnancy is now considered to be a state of controlled mild maternal systemic inflammation, where circulating levels of pro-inflammatory cytokines, including TNF $\alpha$, are raised compared to the non-pregnant state, in a way similar to what happens during sepsis. ${ }^{7}$ These pro-inflammatory cytokines are produced by monocytes and also by trophoblasts. ${ }^{8,9}$ It has been hypothesized that during normal pregnancy, there is a subtle immunological shift to the Th2-type cytokine responses that would suppress the potential harmful effects of the cell-mediated (Th1-type) immune system. ${ }^{3}$ Imbalance in the Th1/Th2 cytokine response with an increase in Th 1 cytokines is associated with adverse pregnancy outcome. ${ }^{5}$
Correspondence: Jean Calleja-Agius Department of Anatomy, Faculty of Medicine and Surgery, University of Malta, Tal-Qroqq, MSD 2080, Malta Tel 0035621693041

Fax 003562 2I I 9527

Email jean.calleja-agius@um.edu.mt 


\section{Structure and bioactivities of TNF $\alpha$ receptors}

$\mathrm{TNF} \alpha$ is a potent, multifunctional cytokine in autocrine and paracrine processes central to reproduction. These processes include gamete, follicle and luteal development, steroidogenesis, uterine cyclicity, placental differentiation, development of the embryo, and parturition..$^{10}$ The biological activities of TNF $\alpha$ are mediated via two different TNF $\alpha$ receptors (TNF-Rs): TNF-R1 (also known as p55/p60, Type I, b, TNF-R55, TNF-R $\beta$ or CD120a) with a molecular mass of 55-60 kDa; and TNF-R2 (or p75/p80, Type II, a, TNF-R75, TNF-R $\alpha$ or CD120b), weighing $75-80 \mathrm{kDa}^{11,12}$ (Table 1).

The differential expression of the two TNF-Rs is regulated by female sex steroid hormones. These two receptors consist of a homologous extracellular, cysteine-rich transmembrane domain, but their intracellular domains are entirely different, and each receptor is independently regulated. Although each receptor induces distinct intracellular signals, they also have co-operative and overlapping effects. In cells responding to TNF $\alpha$ via the TNF-R1, the extracellular part of TNF-R2 captures TNF $\alpha$, even at low concentrations, and delivers it to TNF-R1, resulting in an enhanced response to TNF $\alpha .{ }^{13}$

Depending on cell type and activation status, the number of receptors per cell ranges from 100 to 10,000 copies. ${ }^{14,15}$ The TNF-R1 is found on most tissues, and seems to be the main mediator of TNF $\alpha$ signaling, leading to pro-inflammatory and programmed cell death pathways, and is therefore associated with cytotoxicity. TNF-R1 carries out most of the activities of TNF $\alpha$, especially those that are rapid, while TNF-R2 is involved in the late long-term effects of this cytokine. TNF-R2 is more prevalent in immune cells ${ }^{11,16}$ and is primarily associated with lymphocyte proliferation. While TNF-R2 may induce apoptosis, ${ }^{17}$ it can also enhance tissue repair and angiogenesis, thus promoting cell survival. ${ }^{18}$ Other biological activities of TNF-Rs include gene induction in endothelial cells, inducing cytokine production, and activation of nuclear factor kappa-light-chain-enhancer of B cells. ${ }^{15,19,20}$

Both receptors can have their extracellular domains cleaved from the membrane, thus forming soluble TNF-Rs. The soluble TNF-Rs are present in the serum and urine and have been shown to protect against the harmful effects of excessive TNF $\alpha$ by neutralizing this cytokine. ${ }^{21}$ The soluble form of TNF-R2 is cleaved by proteolysis through the metalloproteinase TNF $\alpha$ converting enzyme (TACE, also known as ADAM17). ${ }^{22,23}$ Soluble TNF-R2 is involved in the inactivation of TNF $\alpha$ in the circulation by the formation of high affinity complexes. This subsequently reduces the binding of TNF $\alpha$ to target cell membrane receptors and downregulates the response to TNF $\alpha .{ }^{24}$ The proteolytic enzyme that releases soluble TNF-R1 is still unknown. ${ }^{9}$ Lack of soluble TNF-R1 leads to autosomal dominant inherited auto-inflammatory syndromes. ${ }^{25}$

\section{TNF $\alpha$ and its receptors during the normal first trimester}

In situ hybridization studies and immunohistochemical analyses have shown that in non-pregnant women, the expression of TNF $\alpha$ protein in the endometrial glands is negligible in the early proliferative phase, then increases and peaks during the late proliferative phase. In the secretory phase, TNF $\alpha$ protein expression remains high, but slightly less than in the late proliferative phase. ${ }^{26,27}$ Both TNF-Rs follow a similar pattern, with the highest expression in the late secretory phase. ${ }^{28}$

Following decidualisation, TNF $\alpha$ mRNA has been shown to be present in macrophages, ${ }^{29} \mathrm{~T}$-cells, ${ }^{30}$ uterine NK cells, endothelial cells, ${ }^{31}$ and decidual stromal cells

Table I Comparison between TNF-RI and TNF-R2

\begin{tabular}{|c|c|c|}
\hline & TNF-RI & TNF-R2 \\
\hline Other names & p55/p60, Type I, b, TNF-R55, TNF-R $\beta$ or CDI20a & p75/p80, Type II, a, TNF-R75, TNF-R $\alpha$ or CDI20b \\
\hline Molecular weight & $55 \mathrm{kDa}$ & $75-80 \mathrm{kDa}$ \\
\hline Structure & Contains the DD & Does not contain the DD \\
\hline Expressed cell types & $\begin{array}{l}\text { Most tissues, including the proliferating cytotrophoblast } \\
\text { of the cell islands and cell columns, the EVT invading } \\
\text { the decidual tissue, and villous stromal cells }\end{array}$ & Immune cells \\
\hline Functions & $\begin{array}{l}\text { The main mediator of TNF } \alpha \text { signalling, leading } \\
\text { to proinflammatory and programmed cell death pathways, } \\
\text { and cytotoxicity; carries out most of the activities } \\
\text { of } T N F \alpha \text {, especially those which are rapid }\end{array}$ & $\begin{array}{l}\text { Primarily associated with lymphocyte proliferation, } \\
\text { may induce apoptosis, can enhance tissue repair } \\
\text { and angiogenesis; soluble TNF-R2 is involved in the } \\
\text { inactivation of TNF } \alpha \text { in the circulation }\end{array}$ \\
\hline Signaling pathways & Interacts indirectly with TRAF2 via TRADD & Interacts directly with TRAF2 \\
\hline
\end{tabular}

Abbreviations: DD, death domain; EVT, extravillous trophoblasts; TNF $\alpha$, tumor necrosis factor alpha; TRADD, TNF- $\alpha$ receptor-associated death domain; TRAF2, TNFreceptor associated factor 2 . 
in vitro. ${ }^{32,33}$ Other studies have also shown that various decidual cell types express TNF-Rs. ${ }^{9}$ During normal human pregnancy, TNF $\alpha$ gene products have been detected in amniotic fluid ${ }^{34-38}$ and soluble TNF-Rs have been detected in first trimester coelomic fluid. ${ }^{39}$ Since pro-inflammatory cytokines do not cross normal term placenta, ${ }^{40} \mathrm{TNF} \alpha$ and its receptors are probably produced from within the gestational sac from a very early stage in pregnancy. TNF $\alpha$ gene products have been detected in placental supernatants. ${ }^{41,42}$

During the first trimester, all cell types of trophoblastic lineage express TNF $\alpha$ mRNA. These cell types include villous and proliferating cytotrophoblasts, syncytiotrophoblasts, and the extravillous trophoblasts (EVT) invading the uterine wall. ${ }^{43,44}$ Messenger RNA and protein are found in both fully differentiated syncytiotrophoblasts ${ }^{26,45}$ and proliferating EVT cells ${ }^{44}$ during early human gestation. There is a predominance of TNF $\alpha$ in cell columns during invasion especially in the EVT as it displaces the endothelial cells of the spiral arteries. ${ }^{46,47}$

TNF-R1 mRNA has been identified in the proliferating cytotrophoblast of the cell islands and cell columns, the EVT invading the decidual tissue ${ }^{48}$ and villous stromal cells. ${ }^{49}$ There is also a non-uniform distribution of TNF-R1 mRNA in villous cytotrophoblasts and syncytiotrophoblasts in the first trimester placenta. ${ }^{9}$ During early gestation, TNF-R1 protein is expressed widely in villous cytotrophoblasts, EVT and cell columns, and trophoblasts. ${ }^{48}$ As for syncytiotrophoblasts, TNF-R1 has been shown to be present during all gestational ages..$^{50}$ Under inflammatory conditions, soluble TNF-R1 may protect the trophoblast from the cytotoxic effects of TNF $\alpha{ }^{48}$

TNF-R2 mRNA has a similar distribution to TNF-R1 mRNA. TNF-R2 mRNA has been observed in cultures of first trimester trophoblasts, but to a lesser extent than TNF-R $1 .{ }^{48}$ It is yet not clear how TNF-R2 is expressed in the placenta. ${ }^{9}$ Studies show that TNF-R2 mRNA is restricted to the trophoblast in early pregnancy and, at later stages, shifts to placental mesenchymal cells. ${ }^{49}$

It has been proposed that placental TNF $\alpha$ derived from macrophages, possibly modulated by TNF $\alpha$-TNFRI signaling, facilitates trophoblast differentiation. ${ }^{48,51} \mathrm{TNF} \alpha$ at the fetal-maternal interface plays an important role in regulating macrophage recruitment by trophoblast cells. It has been shown that media conditioned by TNF $\alpha$-treated trophoblast cells significantly enhance the ability of the monocyte cell line THP-1 to invade through Matrigel. ${ }^{52}$ TNF $\alpha$ might promote proliferation of trophoblast and increased human chorionic gonadotrophin secretion by acting as an autocrine growth factor via TNF-RI. ${ }^{44}$

\section{Systemic and placental levels of TNF $\alpha$ and its receptors in pregnancy}

Prospective longitudinal studies of cytokine expression in the circulation during normal pregnancy show that as pregnancy progresses, there is an overall decrease in pro-inflammatory cytokines such as TNF $\alpha$ and IFN $\gamma$, accompanied by an increase in the anti-inflammatory cytokines such as IL-10 and IL-6. ${ }^{53,54}$ Successful pregnancy requires a delicate balance in Th1/ Th2 cytokines. Plasma levels of TNF $\alpha$ and the neutralizing soluble receptor TNF-R2 rise till the second trimester, and then decrease. ${ }^{55}$ This is followed by a shift towards Th2 cytokines in the second trimester with an increase in Th2 cytokines till term. ${ }^{54}$ As pregnancy progresses, there is a change in placental expression of TNF $\alpha .{ }^{26}$ As for TNF-Rs, TNF-RI mRNA and protein are expressed in essentially all types of cells of the human placenta, with increasing levels as the pregnancy advances to term. ${ }^{39}$ This suggests that TNF $\alpha$ and its receptors may have a specific role in the process of developmental differentiation. Later in pregnancy, TNF $\alpha$ mRNA is more prominent in placental macrophages within villous stromal cells than in trophoblasts. ${ }^{26,56}$ In the third trimester, there is less expression of TNF $\alpha$ protein in invasive cells, and no expression at all in trophoblast giant cells. ${ }^{57} \mathrm{TNF} \alpha \mathrm{mRNA}$ and protein are prominent in macrophage-like cells present in term placentas and extraplacental membranes. $.^{26,29} \mathrm{TNF}-\mathrm{R} 1 \mathrm{mRNA}$ is also present in high amounts in the villous stroma and endothelial cells, and to a lower extent in the syncytiotrophoblasts of the term placenta ${ }^{49}$ In cultured third trimester villous cytotrophoblasts, cytotoxic effects of TNF $\alpha$, both alone and in combination with IFN $\gamma$, have been demonstrated, predominantly induced through TNF-R $1 .{ }^{58}$ There are elevated concentrations of soluble TNF-Rs in the urine of pregnant women. ${ }^{59}$ This can be explained by the in vitro finding that third trimester trophoblast cells rapidly release soluble TNF-R1 and TNF-R2 into the culture medium. ${ }^{60}$ Pregnancy specific glycoproteins derived from the placenta increase the secretion of IL-10 and other anti-inflammatory cytokines. IL-10 downregulates activity of $\mathrm{TNF} \alpha$ by inhibiting the release of TNF $\alpha$, increasing the release of soluble TNF-R1 and -R2, and reducing the surface expression of both TNF-Rs. ${ }^{61}$

Total antioxidant activity of amniotic fluid samples from asymptomatic mid-trimester women positively correlate with soluble TNF-Rs. ${ }^{62}$ TNF $\alpha$ is important in the initiation and amplification of inflammation. ${ }^{63}$ TNF-Rs may reduce oxidative stress due to receptor binding of the inflammatory TNF $\alpha$. 
Many cell types present in the endometrium, placenta and deciduas have been shown to express TNF $\alpha$ and its receptors, implying that multiple autocrine and paracrine interactions can occur. ${ }^{9}$ Although there are complementary roles for the TNF-receptors, TNF-R1 has been shown to be mainly involved in apoptosis in the placenta. ${ }^{58}$

\section{TNF $\alpha$ and its receptors in miscarriage}

The balance between pro- and anti-inflammatory cytokines is essential for implantation, placental development and pregnancy outcome. Changes in the Th1/Th2 balance in the feto-maternal interface in favor of Th1 can lead to adverse pregnancy outcome, including recurrent spontaneous miscarriages. ${ }^{64}$ Increased Th 1 cytokines, including TNF $\alpha$, have been found in women suffering from recurrent spontaneous miscarriages. ${ }^{65}$ It was also demonstrated that women with recurrent spontaneous miscarriages had reduced levels of soluble TNF-R1 and TNF-R2, which were then normalized upon administration of progesterone. ${ }^{66}$ Once treated with TNF $\alpha$ inhibitors, this group of women had an increase in the rate of live births. ${ }^{67} \mathrm{TNF} \alpha$ is unlikely to be the only mediator and, in most cases of miscarriage, there are additional triggers. ${ }^{9}$ Evidence shows that TNF $\alpha$, IFN $\gamma$ and NK cells cannot induce miscarriage separately, but a Th1-NK-macrophage triad may bring about miscarriage, which can in turn be suppressed by a Th2 cytokine response. ${ }^{3,68}$

Immunohistochemical studies have shown abundant mTNF-R1 expression in the cytotrophoblasts, villous stromal cells and vessel endothelial cells derived from placenta from women with early spontaneous miscarriage. Over-expression of TNF-R1 may mediate TNF $\alpha$ to induce apoptosis in these cells, leading to tissue damage in chorionic villi in non-viable pregnancies. ${ }^{69}$ Mice studies are showing that TNF $\alpha$ via TNFR1 signaling causes placental pathology leading to fetal hypoxia, which can be prevented by TNF $\alpha$-antagonists. ${ }^{70}$

\section{TNF $\alpha$ and its receptors in preterm labor}

Parturition is a complex process, brought about by the right combination of signals, following mechanical and endocrine stimulation. ${ }^{71}$ Prematurity occurs in the case of aberrations in these signals, together with inflammation, cervical abnormalities and/or progesterone resistance. However the major mechanism of preterm labor is still unclear. Complications of pregnancy have been associated with deficient conversion of the uterine spiral arteries, leading to abnormal placental perfusion. Placental malperfusion can cause oxidative stress, ${ }^{72}$ induced by an ischemia-reperfusion-type insult, ${ }^{73}$ leading to a rise in pro-inflammatory cytokines and anti-angiogenic factors in the maternal circulation.

In the case of late miscarriages and premature labor, TNF $\alpha$ and other pro-inflammatory cytokines have been shown to stimulate uterine activity and cervical ripening by producing prostaglandins ${ }^{74}$ and cortisol, ${ }^{75}$ and degrade the extracellular matrix of chorio-amniotic membranes via MMP-2 and MMP-9. ${ }^{76}$ Oxidative stress and inflammatory cytokines are powerful inducers of apoptosis and necrosis. TNF $\alpha$, together with other pro-inflammatory cytokines such as IL-1 $\beta$, are elevated in the amniotic fluid of women with preterm labor and/or preterm premature rupture of membranes (PPROM), even in the absence of infection. ${ }^{77-79}$ Pro-inflammatory cytokines can stimulate production of prostaglandins, leading to uterine contractions, and upregulation of MMP activation. Intra-amniotic inflammation may lead to apoptosis, thus weakening fetal membranes and leading to PPROM..$^{80,81}$

In PPROM, two major apoptotic pathways have been implicated. The first is a TNF $\alpha$ receptor-Fas-mediated pathway. This initiates signal transduction through 2 docking proteins known as TRADD (TNF- $\alpha$ receptor-associated death domain) and FADD (Fas-associated death domain), which in turn activate pro-caspase- 8 to active caspase- 8 (Figure 1). The other apoptotic pathway is p53-mediated, initiated by DNA fragmentation with activation of caspase-9. Caspase- 8 and -9 initiate a cascade of caspase activation, followed by sequential activation of caspases 3, 7 and 6 , leading to proteolysis of structural proteins, proteins of homeostasis, and several other target proteins leading to apoptosis. $^{82}$

Lipopolysaccharide (LPS)-induced apoptosis in macrophages has been attributed to the LPS-mediated induction of pro-apoptotic TNF $\alpha$ acting back on the cells in an autocrine/paracrine manner. ${ }^{83}$ LPS triggers TNF $\alpha$ production in fetal membranes. ${ }^{84}$ Elevated endotoxin levels are found in the amniotic fluid of women with preterm labor and PPROM. ${ }^{85}$ Endotoxin is capable of stimulating prostaglandin production in amnion cells, and can initiate preterm labor via the host inflammatory response through activation of immunocytes and release of inflammatory cytokines ${ }^{86}$ Elevated levels of $\mathrm{TNF} \alpha$, together with other pro-inflammatory cytokines such as IL-1, are found in women with intra-amniotic infection and preterm labor, and, in turn, these cytokines stimulate prostaglandin synthesis in human tissues. ${ }^{74,85,87}$ The mRNA from $\mathrm{TNF} \alpha$ and other pro-inflammatory cytokines is expressed in human fetal membranes in response to infection and endotoxin stimulation..$^{88}$ Infection is closely involved in the process of preterm birth, partly through the host response via 


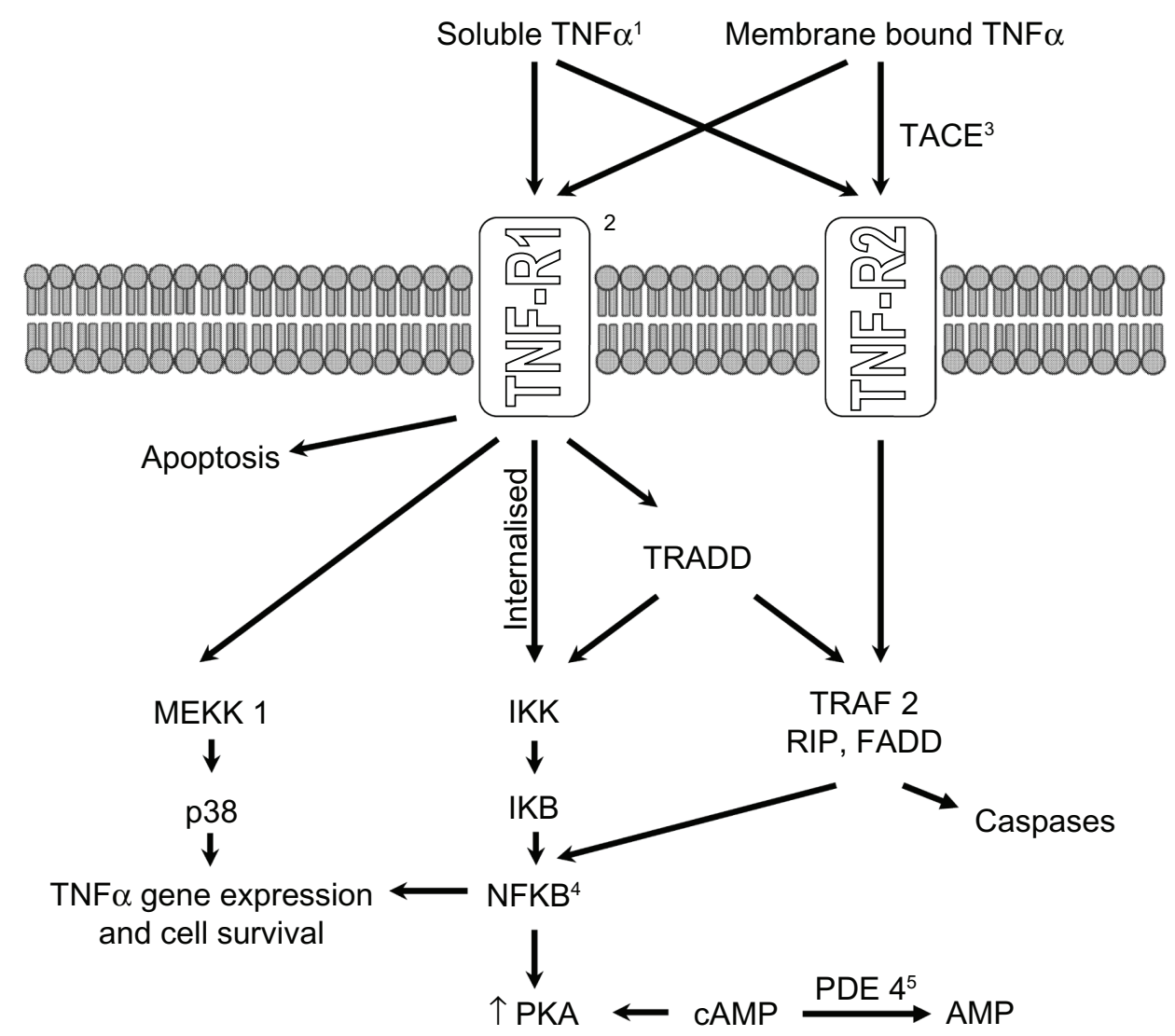

Figure I TNF- $\alpha$ signaling and the potential targets for the inhibition of TNF- $\alpha$-related activities.

Notes: Inhibitors can target the TNF- $\alpha$ molecule (1) or its receptor (2), preventing the resultant signaling pathways. Another target includes TACE (3), which processes the 26-kDa membrane form of TNF- $\alpha$ to the soluble 17-kDa form preventing its release into the circulation. Inhibition of the activation of NF- $\kappa-B$ (4) prevents the synthesis of NF-K-B inducible genes, including many pro-inflammatory cytokines. Molecules targeting intracellular TNF- $\alpha$-related signaling pathways have also been identified, including inhibitors of P38 and PDE4 (5). ${ }^{204,205}$

Abbreviations: cAMP, cyclic AMP; DD, death domain; IB, inhibitor of NF-B; IKK, IB kinase; MEKKI, mitogen-activated protein kinase kinase kinase I; NF-B, nuclear factor-B; NIK, NF-B-inducing kinase; PDE4, phosphodiesterase 4; PKA, protein kinase A; RIP, receptor-interacting protein; TACE, TNF-coverting enzyme; TNF-, tumor-necrosis factor-; TNFRI, TNF-receptor I; TRADD, TNFRI-associated death-domain-containing protein; TRAF2, TNFR-associated factor 2.

the inflammatory cytokine release, and its effect on starting uterine activity. ${ }^{85} \mathrm{TNF} \alpha$ and other pro-inflammatory cytokine levels in the amniotic fluid increase towards term and in normal labor. However, there is an increase in TNF $\alpha$ released from the amniochorion, together with other pro-inflammatory cytokines in the amniotic fluid of women with preterm labor caused by intra-amniotic infection.

Women with preterm labor or PPROM have an elevated concentration of IL- $6^{89}$ and $\mathrm{TNF} \alpha^{90}$ in the amniotic fluid, compared to women whose preterm labor did not progress to preterm delivery. ${ }^{91}$ Increased TNF $\alpha$, together with IL-6, IL-1 $\alpha$, IL-1 $\beta$, and PGE2 are associated with histologic chorioamnionitis among women who delivered within 1 week of amniocentesis. ${ }^{90}$ Ex vivo incubation of whole unprocessed amniotic fluid may provide a more accurate indication of the cytokine release from amniotic cells, than just measuring the soluble components in the unincubated amniotic fluid supernatant (similar to using whole blood rather than peripheral blood mononuclear cells). ${ }^{92}$
TNF $\alpha$ levels present in amniotic fluid are in the picogram per milliliter range. ${ }^{93}$ TNF $\alpha$ peptide is present only in the amnion, but chorionic cells also have mRNA for TNF $\alpha{ }^{88}$ TNF $\alpha$ has been detected in less than half of amniotic fluid samples in midtrimester, and even less in cases of preterm delivery. ${ }^{62}$ In Caucasians, midtrimester levels of TNF $\alpha$ and soluble TNF-Rs in symptomatic women are not significantly different between patients with preterm birth and those who proceed to term. ${ }^{36,62}$ Elevated TNF $\alpha$ concentration in amniotic fluid is associated with preterm birth and PPROM, ${ }^{94,93}$ and the bioavailability of TNF $\alpha$ and its receptors influences the pathophysiology of these outcomes. ${ }^{95}$ During an ascending infection, the choriodecidua is the first line barrier for pathogens such as E.coli, that can cross the amniotic membranes and into the amniotic fluid. ${ }^{96}$ In response to this ascending infection, there is abnormal production of TNF $\alpha$ in the amnion compartment when the pathogen affects both the amniotic membrane and the choriodecidua in vitro (comparable to chorioamnionitis in vivo). ${ }^{97}$ 
Asymptomatic intra-amniotic infection is confirmed when micro-organisms are cultured in amniotic fluid obtained during amniocentesis. However, since culture results may take several days, measuring pro-inflammatory cytokines in amniotic fluid by enzyme-linked immunosorbent assay, as markers of intrauterine infection, may provide a quicker way of predicting preterm labor. TNF $\alpha$ is not normally detected in amniotic fluid in the 2nd and 3rd trimester, but rises during normal labor or in pathologic conditions such as intrauterine infection. ${ }^{80,93,98}$ IL-6 present in the amniotic fluid has been linked with chorioamnionitis. ${ }^{99}$ Elevated TNF $\alpha>6.6 \mathrm{pg} / \mathrm{mL}$ and IL-6 $>99.3 \mathrm{pg} / \mathrm{mL}$ levels in amniotic fluid samples obtained in asymptomatic women during second trimester amniocentesis can identify patients at risk for intra-amniotic infection (sensitivity of $78.4 \%$ and $91.9 \%$ and specificity of $70.1 \%$ and $73.8 \%$ ) and preterm delivery (sensitivity of $81.3 \%$ and $89.6 \%$ and specificity of $79.2 \%$ and $80.3 \%$ ). ${ }^{37}$ However, studies have shown that some patients with a positive amniotic fluid culture and low levels of pro-inflammatory cytokines, still had preterm delivery. This could be due to a low maternal response due to functional polymorphism and/ or some bacterial endotoxins may not be potent enough to stimulate the pro-inflammatory cytokine response. ${ }^{100}$

It is still unclear whether cytokines in the maternal circulation can predict preterm labor, before symptoms of preterm labor or PPROM start. TNF $\alpha$ has been considered as a marker of preterm labor, together with other inflammatory cytokines such as IL-1B, because it can activate uterotonins and increase synthesis of prostaglandins, which can induce labor in non-human primates. ${ }^{101-103} \mathrm{~A}$ number of studies report elevated levels of pro-inflammatory cytokines in midpregnancy amniotic fluid, ${ }^{104}$ maternal serum and cervical samples ${ }^{105,106}$ among women with preterm delivery, and even in placental tissues ${ }^{107-109}$ of spontaneous preterm deliveries. In the Preterm Prediction Study, the use of a combination of tests such as maternal serum alpha-fetoprotein, alkaline phosphatase, GM-CSF, fetal fibronectin and cervical length could enhance prediction of spontaneous preterm birth. ${ }^{110}$

Cytokines in the circulation are more non-specific than amniotic fluid or cervical fluid cytokines, because they might reflect a combination of a maternal acute-phase response accompanying the local inflammation, together with cytokines derived from the feto-placental unit. Therefore, the lack of association between preterm and midterm pregnancy circulatory cytokine levels in asymptomatic women suggest that inflammation occurring in the feto-placental unit may not always be reflected in maternal serum levels of TNF $\alpha$ and other cytokines. Also, the timing of inflammation in pregnancy is probably very important, with inflammation occurring in the first trimester having a more significant association with adverse pregnancy outcome. ${ }^{111}$

By contrast, plasma cytokine levels have been measured in a case-control study among Danish women at 25 weeks' gestation, using multiplex flow cytometry (Luminex Corporation, Austin, TX). Elevated TNF $\alpha$ levels $>75$ th and $>90$ th percentile do not differ by gestational age at delivery, and therefore are not associated with an increased risk of preterm delivery. There is an increased risk of preterm birth with elevated IFN $\gamma$ and IL-6. ${ }^{12}$ Therefore, there appears to be only limited value in using mid-pregnancy cytokines in predicting spontaneous preterm birth. During preterm labor, serum levels of IL-6, IL-8 and TNF $\alpha$ are not increased when compared to normal control women. ${ }^{113}$

Bacterial intrauterine infection stimulates maternal immune cells to produce pro-inflammatory cytokines. ${ }^{114}$ In non-human primates, inoculation of the amniotic cavity with TNF $\alpha$ or IL-1 $\beta$ induces preterm labour. ${ }^{101,115}$ In mice, TNF $\alpha$ causes preterm birth, ${ }^{116}$ while TNF $\alpha$-antibodies block LPSinduced preterm birth. ${ }^{117}$ Most infections leading to preterm birth are subclinical, and it may be possible that women who undergo a preterm birth have an increased immune response to the causative bacteria. There have been largely conflicting results regarding TNF $\alpha$ gene promoter polymorphisms that may increase the risk of preterm birth, ${ }^{118}$ and it is likely that either these polymorphisms alone do not cause preterm birth in the absence of infection, ${ }^{119}$ or else these polymorphisms do not increase TNF $\alpha$ secretion. Women with a history of preterm birth have an elevated TNF $\alpha$ production in response to LPS relative to controls. ${ }^{120}$ However, in another study, peripheral blood mononuclear cells from women with a history of preterm birth have not produced significantly different amounts of TNF $\alpha$ in response to E.Coli, Group B Streptococci (S. agalactiae) and U.urealyticum (bacterial species causing preterm birth in animal species) compared to women with prior uncomplicated term deliveries. ${ }^{121}$

Cytokine profiles, especially TNF $\alpha$, differ between different ethnic groups and by pregnancy outcome. ${ }^{36,122}$ In pregnancy, the function of TNF $\alpha$ is determined by its specific binding to one of its two receptors: MMP activation and apoptosis through TNFR1 and Nk-kB activation, leading to overall enhancement of inflammation through TNFR2.$^{80}$ The soluble forms of these membrane receptors bind to TNF $\alpha$ with high affinity and can neutralize TNF $\alpha$ function..$^{95,125-125}$ There is a difference in the co-ordination between TNF $\alpha$ and its receptors between peoples (African Americans and Caucasians) with respect to preterm versus term delivery. 
In Caucasians, midtrimester levels of TNF $\alpha$ and soluble TNF-Rs in symptomatic women are not significantly different between patients with preterm birth and those who proceed to term. ${ }^{36,62}$ Elevated TNF $\alpha$ concentration in amniotic fluid is associated with preterm birth and PPROM, ${ }^{93,94}$ and the bioavailability of TNF $\alpha$ and its receptors influences the pathophysiology of these outcomes. ${ }^{95}$ During an ascending infection, the choriodecidua is the first line barrier for pathogens such as E.coli, that can cross the amniotic membranes and into the amniotic fluid. ${ }^{96}$ In response to this ascending infection, there is abnormal production of $\mathrm{TNF} \alpha$ in the amnion compartment when the pathogen affects both the amniotic membrane and the choriodecidua in vitro (comparable to chorioamnionitis in vivo). ${ }^{97}$

TNF $\alpha$ is produced by both maternal and fetal tissues, and increases the production of prostaglandins, myometrial activity, induction of MMPs and apoptosis, all of which can lead to preterm labor, irrespective of infection. ${ }^{81,93} \mathrm{In}$ amniotic membrane samples taken from the placenta of Caucasian women, there is a pronounced increase in TNF $\alpha$ concentration in response to endotoxin stimulation, compensated by an increase in soluble TNFRs. The latter is not evident in African Americans. ${ }^{126}$ In amniotic fluid taken prior to labor (term or preterm) in African Americans (but not in Caucasians), there is increased TNF $\alpha$ bioavailability (higher TNF $\alpha$ compared to soluble TNFR1 and TNFR2) in women who deliver preterm compared to those who deliver at term. ${ }^{36}$ Therefore, in Caucasians, but not in African Americans, TNF $\alpha$ changes in preterm labor are compensated by changes in soluble receptors. ${ }^{36,122}$

This phenotypic difference of African Americans having a significant cytokine imbalance is caused by variation in the genes encoding these proteins, with significant differences between allelic, genotypic and haplotypic frequency differences in TNF $\alpha$ and TNF $\alpha$ receptor genes between different peoples. ${ }^{118,127}$ However, no association has been observed between these single nucleotide polymorphisms, including the $\mathrm{TNF} \alpha$ promoter functional variant (-308) and other markers in the TNF $\alpha$ and TNF $\alpha$ receptor genes, and preterm birth. ${ }^{127}$ This may be due to gene-environment interactions, with the effects of some single nucleotide proteins differing as a function of specific environmental factors. The presence of the TNF $\alpha$ risk allele at -308 can modify pregnancy outcome through interactions with bacterial vaginosis and periodontitis, even in the absence of an independent single locus effect. ${ }^{98,119,128}$ Therefore, genetic regulation of TNF $\alpha$ and soluble TNF-Rs concentrations in amniotic fluid is affected by ethnicity and preterm birth. ${ }^{34}$ In Caucasians, TNF-Rs in the amniotic fluid are higher in preterm than in term patients; but in African Americans, amniotic fluid TNF-Rs are higher in term versus preterm patients. ${ }^{34}$ The disparity in inflammatory cytokine profiles found in amniotic fluid can partly explain the higher rate of preterm birth among African Americans and Caucasians in the United States. In African Americans with term birth, TNF $\alpha$ and IL-10 concentrations in amniotic fluid are positively correlated, indicating a generalized inflammatory status during labor, but there is a negative correlation coefficient in preterm birth with an overwhelming increase in TNF $\alpha$ not being co-ordinated by IL- $6 .{ }^{129}$ In this ethnic group, preterm labor is mediated predominantly by TNF $\alpha$ and IL-1 $\beta .{ }^{101} \mathrm{IL}-10$ levels correlated with soluble TNFR1 and TNFR2 in preterm, confirming immunoinhibitory mechanisms during preterm labor, which are overwhelmed by the increase in TNF $\alpha$ and IL-1. Therefore, the pathways leading to preterm birth may be different in the two ethnic groups. ${ }^{130}$

There are probably other unmeasured (environmental) factors that interact to alter cytokine levels in amniotic fluid. Women with bacterial vaginosis and TNF $\alpha$ promoter polymorphism (-G238A) are at increased risk of delivering preterm, irrespective of ethnicity, ${ }^{131}$ further illustrating a potential gene-environment interaction in preterm delivery. The presence of bacterial vaginosis is associated with elevated levels of TNF $\alpha$ and other pro-inflammatory cytokines, such as IL-1, in the vaginal fluid. ${ }^{132,133}$ In vitro experiments with decidual and amniotic cells, these pro-inflammatory cytokines are able to induce the release of prostaglandins and MMPs. ${ }^{134,135}$ Therefore, high levels of TNF $\alpha$ in the presence of bacterial vaginosis may stimulate contractions and/or degradation of membranes.

It has been shown that during maternal infection, TNF $\alpha$ and IFN $\gamma$ increase the production of prostaglandins, resulting in premature labor. ${ }^{136,137} \mathrm{~A}$ positive association has been shown between elevated levels of pro-inflammatory cytokines, including TNF $\alpha$, IFN $\gamma$, IL-1, and IL-8. ${ }^{138-140}$ Studies have shown conflicting evidence as to whether increasing levels of TNF $\alpha$ are associated with an increased risk of intra-uterine growth restriction. ${ }^{141-143}$ In a recent study, higher levels of TNF $\alpha$ in umbilical cord blood was associated with preterm delivery, but not with intra-uterine growth restriction. ${ }^{144}$ Interestingly, higher levels of other pro-inflammatory markers in the umbilical cord blood, such as IFN $\gamma$ and interleukin 12p70, are associated with decreased risk of small for gestational age. ${ }^{144}$

\section{TNF $\alpha$ and preeclampsia}

Preeclampsia is a potentially life-threatening complex multisystem maternal disorder that can occur in the second 
half of pregnancy, labor or the early postpartum period. It is characterized by high blood pressure, proteinuria and other systemic disturbances secondary to diffuse maternal endothelial dysfunction. ${ }^{145}$ Preeclampsia is considered as a state of exaggerated inflammation, in excess of the baseline inflammatory state of normal pregnancy, with local and systemic changes in Th1/Th2 cytokines. ${ }^{146}$ Polymorphisms of cytokine genes may increase the risk of developing preeclampsia. ${ }^{147}$ Peripheral blood mononuclear cells and decidual lymphocytes express higher levels of Th1 cytokines, including TNF $\alpha$, and lower Th2 cytokine expression in preeclampsia compared to normal pregnancy. ${ }^{148,149}$ This is reflected in the maternal circulation, with a further rise in pro-inflammatory cytokines such as TNF $\alpha$, accompanied by an elevated level of soluble receptor in an attempt to dampen the cytokine response. ${ }^{150-153}$ Increased levels of TNF $\alpha$ and other pro-inflammatory cytokines have also been found in the umbilical serum of pregnancies complicated by preeclampsia, suggesting a role in intra-uterine growth restriction secondary to preeclampsia. ${ }^{154}$ The rise in proinflammatory cytokine TNF $\alpha$ and TNF-R1 in maternal circulation increases as early as 11-13 weeks, well before the clinical manifestation of preeclampsia, ${ }^{155}$ but so far has not proved to be useful in screening. ${ }^{156}$

In placental preeclampsia, there is defective placentation with insufficient remodeling of the uterine spiral arteries by the EVT towards the end of the first trimester and in the early second trimester leading to an ischemia-reperfusion phenomenon with subsequent excessive oxidative stress. ${ }^{157}$ It has been shown that placentation is better, with a decrease in incidence of preeclampsia, if the trophoblast strongly stimulates maternal uterine NK cells, which in turn secrete pro-inflammatory cytokines to allow proper invasion. ${ }^{158}$ Activity of decidual NK cells is in turn regulated by a complex network of cytokines. ${ }^{159}$ Pro-inflammatory cytokines such as IL-1 can stimulate MMP-9 and $2^{160}$ and therefore can act as positive regulators of trophoblast differentiation in becoming more invasive. The contrary has been shown for anti-inflammatory cytokines such as IL-10 and transforming growth factor $\beta .^{161,162}$ As mentioned above, there is a predominance of TNF $\alpha$ in cell columns during invasion, especially in the EVT, as it displaces the endothelial cells of the spiral arteries. ${ }^{46,47}$

TNF $\alpha$ and its receptors are expressed in excess both systemically and at the feto-maternal interface ${ }^{146}$ and may play a key role in the pathophysiology of preeclampsia. In preeclampsia, TNF $\alpha$, together with IFN $\gamma$, has been shown to cause apoptosis of cultured cytoblasts and syncytiotrophoblasts, together with impairment of syncytialization, especially under hypoxic conditions in term placenta. ${ }^{163}$ In vitro studies have shown that the combination of TNF $\alpha$ and IFN $\gamma$ inhibit first trimester EVT invasion due to increased apoptosis and reduced proliferation of EVT cells and reduced pro-MMP-2 secretion. ${ }^{164}$ Hypoxia/ re-oxygenation leading to placental oxidative stress is a potent inducer of TNF $\alpha$ secretion by villous explants. ${ }^{73}$ Since there is an elevation of both of these pro-inflammatory cytokines in the placenta of preeclamptic patients, ${ }^{165,166}$ they may have a role in abnormal placentation. TNF $\alpha$ may inhibit migration of EVT in the first trimester placenta via elevated plasminogen activator inhibitor- $1^{167}$ or via activated macrophages. ${ }^{168}$ The sources of TNF $\alpha$ in preeclampsia are the trophoblast cells themselves due to the ischemia-reperfusion insult, ${ }^{56,169}$ as well as the activated maternal monocytes upon adhering to the syncytiotrophoblast. ${ }^{170,171}$ TNF $\alpha$ has also been shown to inhibit the subset of CD4+CD25+ regulatory T lymphocytes. ${ }^{172}$ The latter cells promote fetal tolerance during normal pregnancy, and once inhibited, will not be able to produce immunosuppressive cytokines that are important at the feto-placental interface to prevent fetal rejection. ${ }^{173}$

Preeclampsia is associated with a systemic inflammatory response, which is more exaggerated than what happens in normal pregnancy, due to aberrant cytokine expression. ${ }^{174}$ In early onset preeclampsia, TNF $\alpha /$ IL-10 findings suggest that an imbalance in pro-inflammatory to anti-inflammatory cytokines ratio is associated with unfavorable pregnancy outcomes. ${ }^{175}$ Toll-like receptor (TLR)-4 increases production of TNF $\alpha .{ }^{176}$ TLR is the main danger signaling pathway involved in the pathogenesis of preeclampsia. ${ }^{177}$ TLR2 and TLR4 single nucleotide proteins appear to alter the maternal susceptibility to preeclampsia. ${ }^{178}$

TNF $\alpha$ is a potential mediator of endothelial cell dysfunction, contributing to the systemic effects of preeclampsia. ${ }^{150,179}$ The excess TNF $\alpha$ produced by the placental villous tissue in response to the hypoxia-reperfusion injury affects the endothelial cells by reducing their viability, and upregulating the expression of adhesion molecule E-selectin. ${ }^{56}$ Excess placental production of factors, such as vascular endothelial growth factor receptor-1 (also known as soluble fms-like tyrosine kinase 1 (sFlt-1)), which bind to vascular endothelial growth factor and placental growth factor are anti-angiogenic. ${ }^{180,181}$ They deprive the systemic endothelium of essential survival factors, decreasing the number of adhesion complexes at the cytoplasmic membrane, leading to vascular permeability. ${ }^{182}$ However, the role of cytokines to this particular endothelial response to serum factors 
is still not clear. Elevated angiotensin II type-1 receptor autoantibodies (AT1-AA), together with cytokines, lead to dysfunctional maternal vascular endothelium. ${ }^{183}$ This in turn leads to increased levels of circulating endothelin, reactive oxygen species, and increased vascular sensitivity to angiotensin II, together with lower levels of vasodilators, such as prostacyclin and nitric oxide. ${ }^{184}$ This can lead to multi-organ dysfunction in preeclampsia, including hemolysis, elevated liver enzymes and low platelets syndrome. ${ }^{184,185}$ Sex steroids also play a role in modulating the effect of TNF $\alpha$ on vascular function in preeclampsia. However, in rats, increased levels of ovarian hormones to those observed in pregnancy were not sufficient to induce TNF $\alpha$-induced vascular changes observed in preeclampsia. ${ }^{186}$ Trophoblastic debris, including syncytiotrophoblast membrane microparticles, fetal soluble RNA and DNA, cytokeratin fragments and cytotrophoblast cells, is released into the maternal circulation by apoptotic and necrotic processes in elevated amounts compared to normal pregnancy. This debris is pro-inflammatory and, through the release of cytokines such as $\mathrm{TNF} \alpha$, aggravates maternal inflammation. ${ }^{187}$ It has been shown that placental ischemia leading to preeclampsia is associated with raised inflammatory cytokines such as TNF $\alpha$, and CD4+ T helper cells. ${ }^{188}$

Currently, there is no reliable test that can be used for screening or to facilitate informed decision during management of preeclampsia. Therefore, better understanding of the link between abnormal hemostasis and inflammation in preeclampsia may clarify the underlying pathophysiology, and help design primary preventative and therapeutic measures at an early stage. ${ }^{189}$

\section{TNF $\alpha$-inhibitors and their role in pregnancy}

Over the past 2 decades, anti-TNF $\alpha$ treatment has been developed, including etanercept (Enbrel), a recombinant soluble TNF-R2, and monoclonal TNF $\alpha$-antibodies, such as adalimumab (Humira), infliximab (Remicode) and certolizumab pegol (Cimzia). These have been licensed for use in the treatment of autoimmune diseases such as inflammatory arthritis ${ }^{190}$ and inflammatory bowel disease, ${ }^{191}$ and there is also research showing their possible role in the management of recurrent colorectal cancer. ${ }^{192}$ Because of the immuno-modulatory action of these biologicals, there have been associated increased risks of infections such as viral, tuberculosis and histoplasmosis, and lymphoma. ${ }^{193}$

In an LPS-induced murine model of preterm birth, the use of anti-TNF $\alpha$ treatment decreased fetal deaths and preterm deliveries. ${ }^{117}$ Although regulatory agencies encourage the participation of pregnant and breastfeeding women in randomized controlled trials, this subset of the population has universally been excluded from studies involving the use of anti-TNF $\alpha$ treatment because of unknown or potential risks to the fetus. Thus, strong evidence-based treatment recommendations during pregnancy is lacking, and TNF $\alpha$ inhibitors are listed as Class B, that is, animal reproduction studies have failed to demonstrate fetal risk and there are no well-controlled studies in pregnant women.

Since autoimmune diseases such as Crohn's disease, ulcerative colitis, and rheumatoid, psoriatic, and juvenile idiopathic arthritis are prevalent in women of childbearing age, there have been a number of case reports and registries documenting the effect of the incidental use of anti-TNF $\alpha$ agents in women who inadvertently became pregnant while on treatment. ${ }^{194-196}$ Overall, conflicting results have been produced from these case reports and small case series, partly due to the different timing of when the treatment was taken, other concurrent medication such as methotraxate, and different underlying autoimmune conditions of varying severity. Occurrence of uncommon adverse pregnancy outcomes observed with TNF $\alpha$ inhibitor therapy, such as premature birth, miscarriage, low birth weight, hypertension, and preeclampsia appear to approximate those seen in women not receiving such therapy and may be due to the underlying autoimmune condition itself. ${ }^{197}$ While there is data suggesting little to no risk of congenital anomalies, ${ }^{197}$ a large independent review of the Food and Drug Administration database reports a higher number of VACTERL anomalies in offspring of mothers who were on TNF $\alpha$-antagonists at some point during their pregnancy. ${ }^{198,199}$

VACTERL is a non-random association of birth defects, including vertebral anomalies (V), anal atresia (A), cardiovascular anomalies (C), tracheoesophageal fistula (T), esophageal atresia (E), renal and/or radial anomalies (R) and limb defects (L). So far, the recommendations per observational studies are that women of childbearing age with autoimmune diseases should ideally plan to conceive when their disease is well controlled and while on no medication, and most pregnant patients can discontinue their anti-TNF $\alpha$ treatment early in pregnancy without increasing maternal and fetal risks. ${ }^{197}$

Anti-TNF $\alpha$ treatment has been shown to increase live birth rates in women with recurrent spontaneous abortion ${ }^{67}$ and in a subset of patients with a history of $>2$ failed in-vitro fertilization attempts, ${ }^{200}$ with the latter study having an impressive $100 \%$ pregnancy and $88 \%$ take-home baby rate. In both of the cohort-controlled, non-randomized studies, 
treatment was generally started a month prior to starting a cycle of conception, and continued until a fetal heart was demonstrable by ultrasound. Minimal side-effects and no birth defects were reported. Pretreatment with anti-TNF $\alpha$ is thought to reduce Th1/Th2 levels in CD3+ cells by upregulating regulatory T-cell activity in women with Th1 driven inflammation. ${ }^{201}$ However, in both studies there could have been a selection bias in the choice of patients, because many of the patients without anti-TNF $\alpha$ treatment lacked the high qualifying ratio of Th1/Th2. The karyotype was not tested in the cases of recurrent miscarriage, and the maternalfetal genotype was unknown. There are also other factors controlling reproductive outcome, such as autoantibodies and coagulation defects, therefore using Th1/Th2 ratios alone may not be enough to determine who would benefit from anti-TNF $\alpha$ treatment. Also, one needs to define at what level is Th1/Th2 ratio considered high to merit a beneficial effect from anti-TNF $\alpha$ treatment.

Although the observational studies of Winger et al represent important new data in the field of reproductive immunology, ${ }^{67,200,202,203}$ further prospective randomized controlled studies are needed. Studies in mice are showing that targeting placental TNF $\alpha$ using TNF $\alpha$-antagonists such as etanercept prevents fetal hypoxia and neuroproliferative defects in the fetal brain. ${ }^{70}$ Understanding the mechanism of action of TNF $\alpha$ and its receptors may lead to development of new drugs to decrease the pro-inflammatory effects of this cytokine (Figure 1).

\section{Conclusion}

There is still a lot to be learnt about the role of TNF-R1 and TNF-R2 in normal and complicated pregnancies. Recently, studies have shown that altered levels of these receptors in the circulation, in combination with other cytokines and/ or hormones, may play a role in predicting miscarriage in patients presenting with threatened miscarriage. ${ }^{206}$ Future clinical trials are needed to study the possible benefit of anti-TNF treatment in pregnancy complications.

\section{Disclosure}

The authors declare no conflicts of interest.

\section{References}

1. Mosmann TR, Sad S. The expanding universe of T-cell subsets: Th1, Th2 and more. Immunol Today. 1996;17(3):138-146.

2. Coffman RL, Romagnani S. Redirection of Th1 and Th2 Responses. Berlin: Springer-Verlag; 1999.

3. Wegmann TG, Lin H, Guilbert L, Mosmann TR. Bidirectional cytokine interactions in the maternal-fetal relationship: is successful pregnancy a TH2 phenomenon? Immunol Today. 1993;14(7):353-356.
4. Wilczynski JR. Th1/Th2 cytokines balance - yin and yang of reproductive immunology. Eur J Obstet Gynecol Reprod Biol. 2005;122(2): 136-143.

5. Raghupathy R. Pregnancy: success and failure within the Th1/Th2/Th3 paradigm. Semin Immunol. 2001;13(4):219-227.

6. Chaouat $\mathrm{G}$. The Th1/Th2 paradigm: still important in pregnancy? Semin Immunopathol. 2007;29(2):95-113

7. Sacks GP, Studena K, Sargent K, Redman CW. Normal pregnancy and preeclampsia both produce inflammatory changes in peripheral blood leukocytes akin to those of sepsis. Am J Obstet Gynecol. 1998;179(1):80-86.

8. Kirwan JP, Hauguel-De Mouzon S, Lepercq J, et al. TNF-alpha is a predictor of insulin resistance in human pregnancy. Diabetes. 2002;51(7):2207-2213.

9. Haider S, Knofler M. Human tumour necrosis factor: physiological and pathological roles in placenta and endometrium. Placenta. 2009;30(2):111-123.

10. Terranova PF, Hunter VJ, Roby KF, Hunt JS. Tumor necrosis factor-alpha in the female reproductive tract. Proc Soc Exp Biol Med. 1995;209(4):325-342.

11. Hohmann HP, Remy R, Brockhaus M, van Loon AP. Two different cell types have different major receptors for human tumor necrosis factor (TNF alpha). J Biol Chem. 1989;264(25): 14927-14934

12. Brockhaus M, Schoenfeld HJ, Schlaeger EJ, Hunziker W, Lesslauer W, Loetscher $\mathrm{H}$. Identification of two types of tumor necrosis factor receptors on human cell lines by monoclonal antibodies. Proc Natl Acad Sci U S A. 1990;87(8):3127-3131.

13. Leeuwenberg JF, van Tits LJ, Jeunhomme TM, Buurman WA. Evidence for exclusive role in signalling of tumour necrosis factor $\mathrm{p} 55$ receptor and a potentiating function of $\mathrm{p} 75$ receptor on human endothelial cells. Cytokine. 1995;7(5):457-462.

14. Bigda J, Beletsky I, Brakebusch C, et al. Dual role of the p75 tumor necrosis factor (TNF) receptor in TNF cytotoxicity. J Exp Med. 1994; 180(2):445-460.

15. Vandenabeele P, Declercq W, Beyaert R, Fiers W. Two tumour necrosis factor receptors: structure and function. Trends Cell Biol. 1995;5(10): 392-399.

16. Grell M, Douni E, Wajant H, et al. The transmembrane form of tumor necrosis factor is the prime activating ligand of the $80 \mathrm{kDa}$ tumor necrosis factor receptor. Cell. 1995;83(5):793-802.

17. Wong GH, Tartaglia LA, Lee MS, Goeddel DV. Antiviral activity of tumor necrosis factor is signaled through the 55-kDa type ITNF receptor [corrected]. J Immunol. 1992;149(10):3350-3353.

18. Bradley JR. TNF-mediated inflammatory disease. J Pathol. 2008;214(2): 149-160.

19. Heller RA, Song K, Fan N, Chang DJ. The p70 tumor necrosis factor receptor mediates cytotoxicity. Cell. 1992;70(1):47-56.

20. Barbara JA, Smith WB, Gamble JR, et al. Dissociation of TNFalpha cytotoxic and proinflammatory activities by p 55 receptor- and p75 receptor-selective TNF-alpha mutants. EMBO J. 1994;13(4): 843-850.

21. Fernandez-Botran R. Soluble cytokine receptors: their role in immunoregulation. FASEB J. 1991;5(11):2567-2574.

22. Black RA, Rauch CT, Kozlosky CJ, et al. A metalloproteinase disintegrin that releases tumour-necrosis factor-alpha from cells. Nature. 1997;385(6618):729-733.

23. Van O, X, Tavernier J, Fiers W. Structure-activity studies of human tumour necrosis factors. Protein Eng. 1994;7(1):5-22.

24. Bemelmans MH, Gouma DJ, Buurman WA. LPS-induced sTNFreceptor release in vivo in a murine model. Investigation of the role of tumor necrosis factor, IL-1, leukemia inhibiting factor, and IFN-gamma. J Immunol. 1993;151(10):5554-5562.

25. McDermott MF, Aksentijevich I, Galon J, et al. Germline mutations in the extracellular domains of the $55 \mathrm{kDa}$ TNF receptor, TNFR1, define a family of dominantly inherited autoinflammatory syndromes. Cell. 1999;97(1):133-144. 
26. Chen HL, Yang YP, Hu XL, Yelavarthi KK, Fishback JL, Hunt JS. Tumor necrosis factor alpha mRNA and protein are present in human placental and uterine cells at early and late stages of gestation. Am J Pathol. 1991;139(2):327-335.

27. Hunt JS, Chen HL, Hu XL, Tabibzadeh S. Tumor necrosis factor-alpha messenger ribonucleic acid and protein in human endometrium. Biol Reprod. 1992;47(1):141-147.

28. Hunt JS, Chen HL, Miller L. Tumor necrosis factors: pivotal components of pregnancy? Biol Reprod. 1996;54(3):554-562.

29. Vince G, Shorter S, Starkey P, et al. Localization of tumour necrosis factor production in cells at the materno/fetal interface in human pregnancy. Clin Exp Immunol. 1992;88(1):174-180.

30. Jokhi PP, King A, Sharkey AM, Smith SK, Loke YW. Screening for cytokine messenger ribonucleic acids in purified human decidual lymphocyte populations by the reverse-transcriptase polymerase chain reaction. J Immunol. 1994;153(10):4427-4435.

31. Tabibzadeh S. Ubiquitous expression of TNF-alpha/cachectin immunoreactivity in human endometrium. Am J Reprod Immunol. 1991;26(1):1-4.

32. Jokhi PP, King A, Loke YW. Cytokine production and cytokine receptor expression by cells of the human first trimester placental-uterine interface. Cytokine. 1997;9(2):126-137.

33. Gustafsson C, Hummerdal P, Matthiesen L, Berg G, Ekerfelt C, Ernerudh J. Cytokine secretion in decidual mononuclear cells from term human pregnancy with or without labour: ELISPOT detection of IFN-gamma, IL-4, IL-10, TGF-beta and TNF-alpha. J Reprod Immunol. 2006;71(1):41-56

34. Menon R, Velez DR, Morgan N, Lombardi SJ, Fortunato SJ, Williams SM. Genetic regulation of amniotic fluid TNF-alpha and soluble TNF receptor concentrations affected by race and preterm birth. Hum Genet. 2008;124(3):243-253.

35. Chow SS, Craig ME, Jones CA, et al. Differences in amniotic fluid and maternal serum cytokine levels in early midtrimester women without evidence of infection. Cytokine. 2008;44(1):78-84.

36. Menon R, Thorsen P, Vogel I, et al. Racial disparity in amniotic fluid concentrations of tumor necrosis factor (TNF)-alpha and soluble TNF receptors in spontaneous preterm birth. Am J Obstet Gynecol. 2008;198(5):533-510.

37. Thomakos N, Daskalakis G, Papapanagiotou A, Papantoniou N, Mesogitis S, Antsaklis A. Amniotic fluid interleukin-6 and tumor necrosis factor-alpha at mid-trimester genetic amniocentesis: relationship to intra-amniotic microbial invasion and preterm delivery. Eur $J$ Obstet Gynecol Reprod Biol. 2010;148(2):147-151.

38. Hayashi M, Ueda Y, Yamaguchi T, et al. Tumor necrosis factor-alpha in the placenta is not elevated in pre-eclamptic patients despite its elevation in peripheral blood. Am J Reprod Immunol. 2005;53(3):113-119.

39. Opsjon SL, Novick D, Wathen NC, Cope AP, Wallach D, Aderka D. Soluble tumor necrosis factor receptors and soluble interleukin-6 receptor in fetal and maternal sera, coelomic and amniotic fluids in normal and pre-eclamptic pregnancies. J Reprod Immunol. 1995;29(2):119-134.

40. Aaltonen R, Heikkinen T, Hakala K, Laine K, Alanen A. Transfer of proinflammatory cytokines across term placenta. Obstet Gynecol. 2005;106(4):802-807.

41. Jaattela M, Kuusela P, Saksela E. Demonstration of tumor necrosis factor in human amniotic fluids and supernatants of placental and decidual tissues. Lab Invest. 1988;58(1):48-52.

42. Hunt JS. Expression and regulation of the tumour necrosis factoralpha gene in the female reproductive tract. Reprod Fertil Dev. 1993; 5(2):141-153.

43. King A, Jokhi PP, Smith SK, Sharkey AM, Loke YW. Screening for cytokine mRNA in human villous and extravillous trophoblasts using the reverse-transcriptase polymerase chain reaction (RT-PCR). Cytokine. 1995;7(4):364-371.

44. Yang Y, Yelavarthi KK, Chen HL, Pace JL, Terranova PF, Hunt JS. Molecular, biochemical, and functional characteristics of tumor necrosis factor-alpha produced by human placental cytotrophoblastic cells. J Immunol. 1993;150(12):5614-5624.
45. LiY, Matsuzaki N, Masuhiro K, et al. Trophoblast-derived tumor necrosis factor-alpha induces release of human chorionic gonadotropin using interleukin-6 (IL-6) and IL-6-receptor-dependent system in the normal human trophoblasts. J Clin Endocrinol Metab. 1992;74(1):184-191.

46. Brosens JJ, Pijnenborg R, Brosens IA. The myometrial junctional zone spiral arteries in normal and abnormal pregnancies: a review of the literature. Am J Obstet Gynecol. 2002;187(5):1416-1423.

47. Hering L, Herse F, Verlohren S, et al. Trophoblasts reduce the vascular smooth muscle cell proatherogenic response. Hypertension. 2008;51(2):554-559.

48. Knofler M, Mosl B, Bauer S, Griesinger G, Husslein P. TNF-alpha/ TNFRI in primary and immortalized first trimester cytotrophoblasts. Placenta. 2000;21(5-6):525-535.

49. Yelavarthi KK, Hunt JS. Analysis of p60 and p 80 tumor necrosis factoralpha receptor messenger RNA and protein in human placentas. Am J Pathol. 1993;143(4):1131-1141.

50. Austgulen R, Espevik T, Mecsei R, Scott H. Expression of receptors for tumor necrosis factor in human placenta at term. Acta Obstet Gynecol Scand. 1992;71(6):417-424.

51. Rutherford MS, Schook LB. Differential immunocompetence of macrophages derived using macrophage or granulocyte-macrophage colony-stimulating factor. J Leukoc Biol. 1992;51(1):69-76.

52. Renaud SJ, Sullivan R, Graham CH. Tumour necrosis factor alpha stimulates the production of monocyte chemoattractants by extravillous trophoblast cells via differential activation of MAPK pathways. Placenta. 2009;30(4):313-319.

53. Denney JM, Nelson EL, Wadhwa PD, et al. Longitudinal modulation of immune system cytokine profile during pregnancy. Cytokine. 2010; 53(2):170-177.

54. Aris A, Lambert F, Bessette P, Moutquin JM. Maternal circulating interferon-gamma and interleukin- 6 as biomarkers of Th1/Th2 immune status throughout pregnancy. J Obstet Gynaecol Res. 2008; 34(1):7-11.

55. Beckmann I, Visser W, Struijk PC, van Dooren M, Glavimans J, Wallenburg HC. Circulating bioactive tumor necrosis factor-alpha, tumor necrosis factor-alpha receptors, fibronectin, and tumor necrosis factor-alpha inducible cell adhesion molecule VCAM-1 in uncomplicated pregnancy. Am J Obstet Gynecol. 1997;177(5):1247-1252.

56. Hung TH, Charnock-Jones DS, Skepper JN, Burton GJ. Secretion of tumor necrosis factor-alpha from human placental tissues induced by hypoxia-reoxygenation causes endothelial cell activation in vitro: a potential mediator of the inflammatory response in preeclampsia. $\mathrm{Am}$ J Pathol. 2004;164(3):1049-1061.

57. Pijnenborg R, McLaughlin PJ, Vercruysse L, et al. Immunolocalization of tumour necrosis factor-alpha (TNF-alpha) in the placental bed of normotensive and hypertensive human pregnancies. Placenta. 1998;19(4):231-239.

58. Yui J, Hemmings D, Garcia-Lloret M, Guilbert LJ. Expression of the human p55 and p 75 tumor necrosis factor receptors in primary villous trophoblasts and their role in cytotoxic signal transduction. Biol Reprod. 1996;55(2):400-409.

59. Austgulen R, Liabakk NB, Brockhaus M, Espevik T. Soluble TNF receptors in amniotic fluid and in urine from pregnant women. J Reprod Immunol. 1992;22(2):105-116.

60. Knofler M, Stenzel M, Husslein P. Shedding of tumour necrosis factor receptors from purified villous term trophoblasts and cytotrophoblastic BeWo cells. Hum Reprod. 1998;13(8):2308-2316.

61. Joyce DA, Gibbons DP, Green P, Steer JH, Feldmann M, Brennan FM. Two inhibitors of pro-inflammatory cytokine release, interleukin-10 and interleukin-4, have contrasting effects on release of soluble p75 tumor necrosis factor receptor by cultured monocytes. Eur J Immunol. 1994;24(11):2699-2705.

62. Pressman EK, Thornburg LL, Glantz JC, et al. Inflammatory cytokines and antioxidants in midtrimester amniotic fluid: correlation with pregnancy outcome. Am J Obstet Gynecol. 2011;204(2):155-157.

63. Beutler B, Grau GE. Tumor necrosis factor in the pathogenesis of infectious diseases. Crit Care Med. 1993;21(Suppl 10):S423-S435. 
64. Niederkorn JY. See no evil, hear no evil, do no evil: the lessons of immune privilege. Nat Immunol. 2006;7(4):354-359.

65. Shaarawy M, Nagui AR. Enhanced expression of cytokines may play a fundamental role in the mechanisms of immunologically mediated recurrent spontaneous abortion. Acta Obstet Gynecol Scand. 1997;76(3):205-211.

66. Chernyshov VP, Vodyanik MA, Pisareva SP. Lack of soluble TNFreceptors in women with recurrent spontaneous abortion and possibility for its correction. Am J Reprod Immunol. 2005;54(5):284-291.

67. Winger EE, Reed JL. Treatment with tumor necrosis factor inhibitors and intravenous immunoglobulin improves live birth rates in women with recurrent spontaneous abortion. Am J Reprod Immunol. 2008;60(1):8-16.

68. Arck P, Dietl J, Clark D. From the decidual cell internet: trophoblastrecognizing T cells. Biol Reprod. 1999;60(2):227-233.

69. Faye A, Pornprasert S, Dolcini G, et al. Evaluation of the placental environment with a new in vitro model of histocultures of early and term placentae: determination of cytokine and chemokine expression profiles. Placenta. 2005;26(2-3):262-267.

70. Carpentier PA, Dingman AL, Palmer TD. Placental TNF-alpha signaling in illness-induced complications of pregnancy. Am J Pathol. 2011;178(6):2802-2810.

71. Hirota Y, Cha J, Dey SK. Revisiting reproduction: Prematurity and the puzzle of progesterone resistance. Nat Med. 2010;16(5):529-531.

72. Kim YM, Chaiworapongsa T, Gomez R, et al. Failure of physiologic transformation of the spiral arteries in the placental bed in preterm premature rupture of membranes. Am J Obstet Gynecol. 2002;187(5): 1137-1142.

73. Hung TH, Burton GJ. Hypoxia and reoxygenation: a possible mechanism for placental oxidative stress in preeclampsia. Taiwan J Obstet Gynecol. 2006;45(3):189-200.

74. Christiaens I, Zaragoza DB, Guilbert L, Robertson SA, Mitchell BF, Olson DM. Inflammatory processes in preterm and term parturition. J Reprod Immunol. 2008;79(1):50-57.

75. Dudley DJ. Immunoendocrinology of preterm labor: the link between corticotropin-releasing hormone and inflammation. Am J Obstet Gynecol. 1999;180(1 Pt 3):S251-S256.

76. Ulug U, Goldman S, Ben-Shlomo I, Shalev E. Matrix metalloproteinase (MMP)-2 and MMP-9 and their inhibitor, TIMP-1, in human term decidua and fetal membranes: the effect of prostaglandin F(2alpha) and indomethacin. Mol Hum Reprod. 2001;7(12): 1187-1193.

77. Jacobsson B, Mattsby-Baltzer I, Andersch B, et al. Microbial invasion and cytokine response in amniotic fluid in a Swedish population of women with preterm prelabor rupture of membranes. Acta Obstet Gynecol Scand. 2003;82(5):423-431.

78. Shobokshi A, Shaarawy M. Maternal serum and amniotic fluid cytokines in patients with preterm premature rupture of membranes with and without intrauterine infection. Int $J$ Gynaecol Obstet. 2002;79(3):209-215.

79. Menon R, Swan KF, Lyden TW, Rote NS, Fortunato SJ. Expression of inflammatory cytokines (interleukin-1 beta and interleukin-6) in amniochorionic membranes. Am J Obstet Gynecol. 1995;172(2 Pt 1): 493-500.

80. Fortunato SJ, Menon R, Lombardi SJ. Role of tumor necrosis factor-alpha in the premature rupture of membranes and preterm labor pathways. Am J Obstet Gynecol. 2002;187(5):1159-1162.

81. Menon R, Lombardi SJ, Fortunato SJ. TNF-alpha promotes caspase activation and apoptosis in human fetal membranes. J Assist Reprod Genet. 2002;19(4):201-204.

82. Luo G, Abrahams VM, Tadesse S, et al. Progesterone inhibits basal and TNF-alpha-induced apoptosis in fetal membranes: a novel mechanism to explain progesterone-mediated prevention of preterm birth. Reprod Sci. 2010;17(6):532-539.

83. Xaus J, Comalada M, Valledor AF, et al. LPS induces apoptosis in macrophages mostly through the autocrine production of TNF-alpha. Blood. 2000;95(12):3823-3831.
84. Keelan JA, Khan S, Yosaatmadja F, Mitchell MD. Prevention of inflammatory activation of human gestational membranes in an ex vivo model using a pharmacological NF-kappaB inhibitor. J Immunol. 2009;183(8):5270-5278.

85. Romero R, Manogue KR, Mitchell MD, et al. Infection and labor. IV. Cachectin-tumor necrosis factor in the amniotic fluid of women with intraamniotic infection and preterm labor. Am J Obstet Gynecol. 1989;161(2):336-341.

86. Romero R, Espinoza J, Kusanovic JP, et al. The preterm parturition syndrome. BJOG. 2006;113 Suppl 3:17-42.

87. Casey ML, Cox SM, Word RA, MacDonald PC. Cytokines and infection-induced preterm labour. Reprod Fertil Dev. 1990;2(5): 499-509.

88. Fortunato SJ, Menon R, Swan KF. Expression of TNF-alpha and TNFR p55 in cultured amniochorion. Am J Reprod Immunol. 1994;32(3):188-193.

89. Romero R, Avila C, Santhanam U, Sehgal PB. Amniotic fluid interleukin 6 in preterm labor. Association with infection. J Clin Invest. 1990;85(5):1392-1400.

90. Hillier SL, Witkin SS, Krohn MA, Watts DH, Kiviat NB, Eschenbach DA. The relationship of amniotic fluid cytokines and preterm delivery, amniotic fluid infection, histologic chorioamnionitis, and chorioamnion infection. Obstet Gynecol. 1993;81(6):941-948.

91. Houben ML, Nikkels PG, van Bleek GM, et al. The association between intrauterine inflammation and spontaneous vaginal delivery at term: a cross-sectional study. PloS One. 2009;4(8):e6572.

92. Ojeda OM, Silva CV, de JAR, Fernandez-Ortega C. TNFalpha production in whole blood cultures from healthy individuals. Biochem Biophys Res Commun. 2002;292(2):538-541.

93. Romero R, Mazor M, Sepulveda W, Avila C, Copeland D, Williams J. Tumor necrosis factor in preterm and term labor. Am JObstet Gynecol. $1992 ; 166(5): 1576-1587$.

94. Maymon E, Ghezzi F, Edwin SS, et al. The tumor necrosis factor alpha and its soluble receptor profile in term and preterm parturition. Am J Obstet Gynecol. 1999;181(5 Pt 1):1142-1148.

95. Fortunato SJ, Menon R. Distinct molecular events suggest different pathways for preterm labor and premature rupture of membranes. Am J Obstet Gynecol. 2001;184(7):1399-1405.

96. Romero R, Mazor M. Infection and preterm labor. Clin Obstet Gynecol. 1988;31(3):553-584.

97. Zaga-Clavellina V, Garcia-Lopez G, Flores-Herrera H, et al. In vitro secretion profiles of interleukin (IL)-1beta, IL-6, IL-8, IL-10, and TNF alpha after selective infection with Escherichia coli in human fetal membranes. Reprod Biol Endocrinol. 2007;5:46.

98. Romero R, Chaiworapongsa T, Kuivaniemi H, Tromp G. Bacterial vaginosis, the inflammatory response and the risk of preterm birth: a role for genetic epidemiology in the prevention of preterm birth. Am J Obstet Gynecol. 2004;190(6):1509-1519.

99. El-Bastawissi AY, Williams MA, Riley DE, Hitti J, Krieger JN. Amniotic fluid interleukin-6 and preterm delivery: a review. Obstet Gynecol. 2000;95(6 Pt 2):1056-1064.

100. Yoon BH, Romero R, Moon JB, et al. Clinical significance of intraamniotic inflammation in patients with preterm labor and intact membranes. Am J Obstet Gynecol. 2001;185(5):1130-1136.

101. Sadowsky DW, Adams KM, Gravett MG, Witkin SS, Novy MJ. Preterm labor is induced by intraamniotic infusions of interleukin1 beta and tumor necrosis factor-alpha but not by interleukin- 6 or interleukin-8 in a nonhuman primate model. Am J Obstet Gynecol. 2006;195(6):1578-1589.

102. Lappas M, Permezel M, Rice GE. Advanced glycation endproducts mediate pro-inflammatory actions in human gestational tissues via nuclear factor-kappaB and extracellular signal-regulated kinase 1/2. J Endocrinol. 2007;193(2):269-277.

103. Molnar M, Romero R, Hertelendy F. Interleukin-1 and tumor necrosis factor stimulate arachidonic acid release and phospholipid metabolism in human myometrial cells. Am J Obstet Gynecol. 1993;169(4):825-829. 
104. Wenstrom KD, Andrews WW, Hauth JC, Goldenberg RL, DuBard MB, Cliver SP. Elevated second-trimester amniotic fluid interleukin-6 levels predict preterm delivery. Am J Obstet Gynecol. 1998;178(3): 546-550.

105. Goepfert AR, Goldenberg RL, Andrews WW, et al. The Preterm Prediction Study: association between cervical interleukin 6 concentration and spontaneous preterm birth. National Institute of Child Health and Human Development Maternal-Fetal Medicine Units Network. Am J Obstet Gynecol. 2001;184(3):483-488.

106. Genc MR, Witkin SS, Delaney ML, et al. A disproportionate increase in IL-1beta over IL-1 ra in the cervicovaginal secretions of pregnant women with altered vaginal microflora correlates with preterm birth. Am J Obstet Gynecol. 2004;190(5):1191-1197.

107. Gargano JW, Holzman C, Senagore P, et al. Mid-pregnancy circulating cytokine levels, histologic chorioamnionitis and spontaneous preterm birth. J Reprod Immunol. 2008;79(1):100-110.

108. El-Shazly S, Makhseed M, Azizieh F, Raghupathy R. Increased expression of pro-inflammatory cytokines in placentas of women undergoing spontaneous preterm delivery or premature rupture of membranes. $\mathrm{Am}$ J Reprod Immunol. 2004;52(1):45-52.

109. Holzman C, Lin X, Senagore P, Chung H. Histologic chorioamnionitis and preterm delivery. Am J Epidemiol. October 1, 2007; 166(7):786-794.

110. Goldenberg RL, Iams JD, Mercer BM, et al. The Preterm Prediction Study: toward a multiple-marker test for spontaneous preterm birth. Am J Obstet Gynecol. 2001;185(3):643-651.

111. Curry AE, Vogel I, Skogstrand K, et al. Maternal plasma cytokines in early- and mid-gestation of normal human pregnancy and their association with maternal factors. J Reprod Immunol. 2008;77(2):152-160.

112. Curry AE, Vogel I, Drews C, et al. Mid-pregnancy maternal plasma levels of interleukin 2, 6, and 12, tumor necrosis factor-alpha, interferon-gamma, and granulocyte-macrophage colony-stimulating factor and spontaneous preterm delivery. Acta Obstet Gynecol Scand. 2007;86(9):1103-1110.

113. Bahar AM, Ghalib HW, Moosa RA, Zaki ZM, Thomas C, Nabri OA. Maternal serum interleukin-6, interleukin-8, tumor necrosis factoralpha and interferon-gamma in preterm labor. Acta Obstet Gynecol Scand. 2003;82(6):543-549.

114. Peltier MR. Immunology of term and preterm labor. Reprod Biol Endocrinol. 2003;1:122.

115. Baggia S, Gravett MG, Witkin SS, Haluska GJ, Novy MJ. Interleukin-1 beta intra-amniotic infusion induces tumor necrosis factor-alpha, prostaglandin production, and preterm contractions in pregnant rhesus monkeys. J Soc Gynecol Investig. 1996;3(3):121-126.

116. Silver RM, Lohner WS, Daynes RA, Mitchell MD, Branch DW. Lipopolysaccharide-induced fetal death: the role of tumor-necrosis factor alpha. Biol Reprod. 1994;50(5):1108-1112.

117. Holmgren C, Esplin MS, Hamblin S, Molenda M, Simonsen S, Silver R. Evaluation of the use of anti-TNF-alpha in an LPS-induced murine model. J Reprod Immunol. 2008;78(2):134-139.

118. Menon R, Merialdi M, Betran AP, et al. Analysis of association between maternal tumor necrosis factor-alpha promoter polymorphism (-308), tumor necrosis factor concentration, and preterm birth. Am J Obstet Gynecol. 2006;195(5):1240-1248.

119. Macones GA, Parry S, Elkousy M, Clothier B, Ural SH, Strauss JF III. A polymorphism in the promoter region of TNF and bacterial vaginosis: preliminary evidence of gene-environment interaction in the etiology of spontaneous preterm birth. Am J Obstet Gynecol. 2004;190(6):1504-1508.

120. Amory JH, Hitti J, Lawler R, Eschenbach DA. Increased tumor necrosis factor-alpha production after lipopolysaccharide stimulation of whole blood in patients with previous preterm delivery complicated by intra-amniotic infection or inflammation. Am J Obstet Gynecol. 2001;185(5):1064-1067.

121. Peltier MR, Faux DS, Hamblin SD, Silver RM, Esplin MS. Cytokine production by peripheral blood mononuclear cells of women with a history of preterm birth. J Reprod Immunol. 2010;84(1):111-116.
122. Menon R, Thorsen P, Vogel I, Jacobsson B, Williams SM, Fortunato SJ. Increased bioavailability of TNF-alpha in African Americans during in vitro infection: predisposing evidence for immune imbalance. Placenta. 2007;28(8-9):946-950.

123. Reddy P, Slack JL, Davis R, et al. Functional analysis of the domain structure of tumor necrosis factor-alpha converting enzyme. $J$ Biol Chem. 2000;275(19):14608-14614.

124. Bazzoni F, Beutler B. The tumor necrosis factor ligand and receptor families. N Engl J Med. 1996;334(26):1717-1725.

125. Buckley CA, Rouhani FN, Kaler M, Adamik B, Hawari FI, Levine SJ. Amino-terminal TACE prodomain attenuates TNFR2 cleavage independently of the cysteine switch. Am J Physiol Lung Cell Mol Physiol. 2005;288(6):L1132-L1138.

126. Fortunato SJ, Lombardi SJ, Menon R. Racial disparity in membrane response to infectious stimuli: a possible explanation for observed differences in the incidence of prematurity. Community Award Paper. Am J Obstet Gynecol. 2004;190(6):1557-1562.

127. Menon R, Velez DR, Thorsen P, et al. Ethnic differences in key candidate genes for spontaneous preterm birth: TNF-alpha and its receptors. Hum Hered. 2006;62(2):107-118.

128. Moore S, Ide M, Randhawa M, Walker JJ, Reid JG, Simpson NA. An investigation into the association among preterm birth, cytokine gene polymorphisms and periodontal disease. BJOG. 2004;111(2): $125-132$

129. Velez DR, Fortunato SJ, Morgan N, et al. Patterns of cytokine profiles differ with pregnancy outcome and ethnicity. Hum Reprod. 2008;23(8):1902-1909.

130. Velez DR, Menon R, Thorsen P, et al. Ethnic differences in interleukin 6 (IL-6) and IL6 receptor genes in spontaneous preterm birth and effects on amniotic fluid protein levels. Ann Hum Genet. 2007; 71(Pt 5):586-600.

131. Jones NM, Holzman C, Friderici KH, et al. Interplay of cytokine polymorphisms and bacterial vaginosis in the etiology of preterm delivery. J Reprod Immunol. 2010;87(1-2):82-89.

132. Sturm-Ramirez K, Gaye-Diallo A, Eisen G, Mboup S, Kanki PJ. High levels of tumor necrosis factor-alpha and interleukin-1 beta in bacterial vaginosis may increase susceptibility to human immunodeficiency virus. J Infect Dis. 2000;182(2):467-473.

133. Hedges SR, Barrientes F, Desmond RA, Schwebke JR. Local and systemic cytokine levels in relation to changes in vaginal flora. $J$ Infect Dis. 2006;193(4):556-562.

134. Oner C, Schatz F, Kizilay G et al. Progestin-inflammatory cytokine interactions affect matrix metalloproteinase- 1 and -3 expression in term decidual cells: implications for treatment of chorioamnionitisinduced preterm delivery. J Clin Endocrinol Metab. 2008;93(1): 252-259.

135. Arechavaleta-Velasco F, Ogando D, Parry S, Vadillo-Ortega F. Production of matrix metalloproteinase-9 in lipopolysaccharide-stimulated human amnion occurs through an autocrine and paracrine proinflammatory cytokine-dependent system. Biol Reprod. 2002;67(6): 1952-1958.

136. Nesin M, Cunningham-Rundles S. Cytokines and neonates. Am J Perinatol. 2000;17(8):393-404.

137. Keelan JA, Blumenstein M, Helliwell RJ, Sato TA, Marvin KW, Mitchell MD. Cytokines, prostaglandins and parturition - a review. Placenta. 2003;24 Suppl A:S33-S46.

138. Hagberg H, Mallard C, Jacobsson B. Role of cytokines in preterm labour and brain injury. BJOG. 2005;112 Suppl 1:16-18.

139. Goldenberg RL, Goepfert AR, Ramsey PS. Biochemical markers for the prediction of preterm birth. Am J Obstet Gynecol. 2005; 192(5 Suppl):S36-S46.

140. Park JS, Park CW, Lockwood CJ, Norwitz ER. Role of cytokines in preterm labor and birth. Minerva Ginecol. 2005;57(4):349-366.

141. Spong CY, Scherer DM, Ghidini A, Pezzullo JC, Salafia CM, Eglinton GS. Midtrimester amniotic fluid tumor necrosis factoralpha does not predict small-for-gestational-age infants. Am J Reprod Immunol. 1997;37(3):236-239. 
142. Hahn-Zoric M, Hagberg H, Kjellmer I, Ellis J, Wennergren M, Hanson LA. Aberrations in placental cytokine mRNA related to intrauterine growth retardation. Pediatr Res. 2002;51(2):201-206.

143. Huang HC, Wang CL, Huang LT, et al. Association of cord blood cytokines with prematurity and cerebral palsy. Early Hum Dev. 2004; 77(1-2):29-36.

144. Neta GI, von Ehrenstein OS, Goldman LR, et al. Umbilical cord serum cytokine levels and risks of small-for-gestational-age and preterm birth. Am J Epidemiol. 2010;171(8):859-867.

145. Redman CW, Sargent IL. Immunology of pre-eclampsia. Am J Reprod Immunol. 2010;63(6):534-543.

146. Rusterholz C, Hahn S, Holzgreve W. Role of placentally produced inflammatory and regulatory cytokines in pregnancy and the etiology of preeclampsia. Semin Immunopathol. 2007;29(2): $151-162$.

147. Vural P, Degirmencioglu S, Saral NY, et al. Tumor necrosis factor alpha, interleukin-6 and interleukin-10 polymorphisms in preeclampsia. J Obstet Gynaecol Res. 2010;36(1):64-71.

148. Matthiesen L, Berg G, Ernerudh J, Ekerfelt C, Jonsson Y, Sharma S. Immunology of preeclampsia. Chem Immunol Allergy. 2005;89:49-61.

149. Jonsson Y, Matthiesen L, Berg G, Ernerudh J, Nieminen K, Ekerfelt C. Indications of an altered immune balance in preeclampsia: a decrease in in vitro secretion of IL-5 and IL-10 from blood mononuclear cells and in blood basophil counts compared with normal pregnancy. J Reprod Immunol. 2005;66(1):69-84.

150. Kupferminc MJ, Peaceman AM, Wigton TR, Tamura RK, Rehnberg KA, Socol ML. Immunoreactive tumor necrosis factor-alpha is elevated in maternal plasma but undetected in amniotic fluid in the second trimester. Am J Obstet Gynecol. 1994;171(4):976-979.

151. Jonsson Y, Ruber M, Matthiesen L, et al. Cytokine mapping of sera from women with preeclampsia and normal pregnancies. J Reprod Immunol. 2006;70(1-2):83-91.

152. Vince GS, Starkey PM, Austgulen R, Kwiatkowski D, Redman CW. Interleukin-6, tumour necrosis factor and soluble tumour necrosis factor receptors in women with pre-eclampsia. Br J Obstet Gynaecol. 1995;102(1):20-25.

153. Mansouri R, Akbari F, Vodjgani M, Mahboudi F, Kalantar F, Mirahmadian M. Serum cytokines profiles in Iranian patients with preeclampsia. Iran J Immunol. 2007;4(3):179-185.

154. Tosun M, Celik H, Avci B, Yavuz E, Alper T, Malatyalioglu E. Maternal and umbilical serum levels of interleukin-6, interleukin-8, and tumor necrosis factor-alpha in normal pregnancies and in pregnancies complicated by preeclampsia. J Matern Fetal Neonatal Med. 2010;23(8):880-886.

155. Williams MA, Farrand A, Mittendorf R, et al. Maternal second trimester serum tumor necrosis factor-alpha-soluble receptor p55 (sTNFp55) and subsequent risk of preeclampsia. Am J Epidemiol. 1999;149(4):323-329.

156. Leal AM, Poon LC, Frisova V, Veduta A, Nicolaides KH. First-trimester maternal serum tumor necrosis factor receptor- 1 and pre-eclampsia. Ultrasound Obstet Gynecol. 2009;33(2):135-141.

157. Jauniaux E, Poston L, Burton GJ. Placental-related diseases of pregnancy: Involvement of oxidative stress and implications in human evolution. Hum Reprod Update. 2006;12(6):747-755.

158. Moffett-King A. Natural killer cells and pregnancy. Nat Rev Immunol. 2002;2(9):656-663.

159. Szekeres-Bartho J. Regulation of NK cell cytotoxicity during pregnancy. Reprod Biomed Online. 2008;16(2):211-217.

160. Meisser A, Chardonnens D, Campana A, Bischof P. Effects of tumour necrosis factor-alpha, interleukin-1 alpha, macrophage colony stimulating factor and transforming growth factor beta on trophoblastic matrix metalloproteinases. Mol Hum Reprod. 1999;5(3): 252-260.

161. Roth I, Fisher SJ. IL-10 is an autocrine inhibitor of human placental cytotrophoblast MMP-9 production and invasion. Dev Biol. 1999;205(1):194-204.
162. Lash GE, Otun HA, Innes BA, Bulmer JN, Searle RF, Robson SC. Inhibition of trophoblast cell invasion by TGFB1, 2, and 3 is associated with a decrease in active proteases. Biol Reprod. 2005;73(2):374-381.

163. Leisser C, Saleh L, Haider S, Husslein H, Sonderegger S, Knofler M. Tumour necrosis factor-alpha impairs chorionic gonadotrophin betasubunit expression and cell fusion of human villous cytotrophoblast. Mol Hum Reprod. 2006;12(10):601-609.

164. Otun HA, Lash GE, Innes BA, et al. Effect of tumour necrosis factoralpha in combination with interferon-gamma on first trimester extravillous trophoblast invasion. J Reprod Immunol. 2011;88(1):1-11.

165. Munno I, Chiechi LM, Lacedra G, et al. Spontaneous and induced release of prostaglandins, interleukin (IL)-1beta, IL-6, and tumor necrosis factor-alpha by placental tissue from normal and preeclamptic pregnancies. Am J Reprod Immunol. 1999;42(6):369-374.

166. Rinehart BK, Terrone DA, Lagoo-Deenadayalan S, et al. Expression of the placental cytokines tumor necrosis factor alpha, interleukin 1beta, and interleukin 10 is increased in preeclampsia. Am JObstet Gynecol. 1999;181(4):915-920.

167. Bauer S, Pollheimer J, Hartmann J, Husslein P, Aplin JD, Knofler M. Tumor necrosis factor-alpha inhibits trophoblast migration through elevation of plasminogen activator inhibitor-1 in first-trimester villous explant cultures. J Clin Endocrinol Metab. 2004;89(2):812-822.

168. Renaud SJ, Postovit LM, Macdonald-Goodfellow SK, McDonald GT, Caldwell JD, Graham CH. Activated macrophages inhibit human cytotrophoblast invasiveness in vitro. Biol Reprod. 2005;73(2): 237-243.

169. Malek A, Sager R, Schneider H. Effect of hypoxia, oxidative stress and lipopolysaccharides on the release of prostaglandins and cytokines from human term placental explants. Placenta. 2001;22 Suppl A: S45-S50.

170. Garcia-Lloret MI, Winkler-Lowen B, Guilbert LJ. Monocytes adhering by LFA-1 to placental syncytiotrophoblasts induce local apoptosis via release of TNF-alpha. A model for hematogenous initiation of placental inflammations. J Leukoc Biol. 2000;68(6):903-908.

171. Seki H, Matuoka K, Inooku H, Takeda S. TNF-alpha from monocyte of patients with pre-eclampsia-induced apoptosis in human trophoblast cell line. J Obstet Gynaecol Res. 2007;33(4):408-416.

172. Valencia X, Stephens G, Goldbach-Mansky R, Wilson M, Shevach EM, Lipsky PE. TNF downmodulates the function of human CD4+CD25hi T-regulatory cells. Blood. 2006;108(1):253-261.

173. Zenclussen AC, Gerlof K, Zenclussen ML, et al. Regulatory T cells induce a privileged tolerant microenvironment at the fetal-maternal interface. Eur J Immunol. 2006;36(1):82-94.

174. Redman CW, Sargent IL. Pre-eclampsia, the placenta and the maternal systemic inflammatory response - a review. Placenta. 2003;24 Suppl A: S21-S27.

175. Xie F, Hu Y, Turvey SE, et al. Toll-like receptors 2 and 4 and the cryopyrin inflammasome in normal pregnancy and pre-eclampsia. BJOG. 2010;117(1):99-108.

176. Mortaz E, Redegeld FA, Nijkamp FP, Wong HR, Engels F. Acetylsalicylic acid-induced release of HSP70 from mast cells results in cell activation through TLR pathway. Exp Hematol. 2006;34(1):8-18.

177. Xie F, Turvey SE, Williams MA, Mor G, von DP. Toll-like receptor signaling and pre-eclampsia. Am J Reprod Immunol. 2010;63(1):7-16.

178. Xie F, Hu Y, Speert DP, et al. Toll-like receptor gene polymorphisms and preeclampsia risk: a case-control study and data synthesis. Hypertens Pregnancy. 2010;29(4):390-398.

179. Greer IA, Lyall F, Perera T, Boswell F, Macara LM. Increased concentrations of cytokines interleukin- 6 and interleukin-1 receptor antagonist in plasma of women with preeclampsia: a mechanism for endothelial dysfunction? Obstet Gynecol. 1994;84(6):937-940.

180. Maynard SE, Min JY, Merchan J, et al. Excess placental soluble fmslike tyrosine kinase 1 (sFlt1) may contribute to endothelial dysfunction, hypertension, and proteinuria in preeclampsia. $J$ Clin Invest. 2003;111(5):649-658.

181. Levine RJ, Karumanchi SA. Circulating angiogenic factors in preeclampsia. Clin Obstet Gynecol. 2005;48(2):372-386. 
182. Groten T, Kreienberg R, Fialka I, Huber L, Wedlich D. Altered subcellular distribution of cadherin-5 in endothelial cells caused by the serum of pre-eclamptic patients. Mol Hum Reprod. 2000;6(11): 1027-1032.

183. LaMarca B, Wallace K, Granger J. Role of angiotensin II type I receptor agonistic autoantibodies (AT1-AA) in preeclampsia. Curr Opin Pharmacol. 2011;11(2):175-179.

184. Lamarca $B$. The role of immune activation in contributing to vascular dysfunction and the pathophysiology of hypertension during preeclampsia. Minerva Ginecol. 2010;62(2):105-120.

185. Tranquilli AL, Landi B, Corradetti A, et al. Inflammatory cytokines patterns in the placenta of pregnancies complicated by HELLP (hemolysis, elevated liver enzyme, and low platelet) syndrome. Cytokine. 2007;40(2):82-88.

186. LaMarca BD, Chandler DL, Grubbs L, et al. Role of sex steroids in modulating tumor necrosis factor alpha-induced changes in vascular function and blood pressure. Am J Hypertens. 2007;20(11):1216-1221.

187. Redman CW, Sargent IL. Latest advances in understanding preeclampsia. Science. 2005;308(5728):1592-1594.

188. Wallace K, Richards S, Dhillon P, et al. CD4+ T-helper cells stimulated in response to placental ischemia mediate hypertension during pregnancy. Hypertension. 2011;57(5):949-955.

189. Dusse LM, Rios DR, Pinheiro MB, Cooper AJ, Lwaleed BA Pre-eclampsia: relationship between coagulation, fibrinolysis and inflammation. Clin Chim Acta. 2011;412(1-2):17-21.

190. Wiens A, Venson R, Correr CJ, Otuki MF, Pontarolo R. Meta-analysis of the efficacy and safety of adalimumab, etanercept, and infliximab for the treatment of rheumatoid arthritis. Pharmacotherapy. 2010; 30(4):339-353

191. Lee TW, Fedorak RN. Tumor necrosis factor-alpha monoclonal antibodies in the treatment of inflammatory bowel disease: clinical practice pharmacology. Gastroenterol Clin North Am. 2010;39(3):543-557.

192. Grimm M, Lazariotou M, Kircher S, et al. Tumor necrosis factor-alpha is associated with positive lymph node status in patients with recurrence of colorectal cancer - indications for anti-TNF-alpha agents in cancer treatment. Anal Cell Pathol (Amst). 2010.

193. Toussirot E, Streit G, Wendling D. Infectious complications with antiTNFalpha therapy in rheumatic diseases: a review. Recent Pat Inflamm Allergy Drug Discov. 2007;1(1):39-47.
194. Roux CH, Brocq O, Breuil V, Albert C, Euller-Ziegler L. Pregnancy in rheumatology patients exposed to anti-tumour necrosis factor (TNF)alpha therapy. Rheumatology (Oxford). 2007;46(4):695-698.

195. Chambers CD, Johnson DL, Jones KL, The OTIS Collaborative Research Group. Pregnancy outcome in women exposed to Anti-TNFalpha medication: the OTIS rheumatoid arthritis in pregnancy study. Arthritis and Rheumatism. 2004:50(90).

196. Wibaux C, Andrei I, Paccou J, et al. Pregnancy during TNFalpha antagonist therapy: beware the rifampin-oral contraceptive interaction. Report of two cases. Joint Bone Spine. 2010;77(3):268-270.

197. Ali YM, Kuriya B, Orozco C, Cush JJ, Keystone EC. Can tumor necrosis factor inhibitors be safely used in pregnancy? J Rheumatol. 2010;37(1):9-17.

198. Carter JD, Ladhani A, Ricca LR, Valeriano J, Vasey FB. A safety assessment of tumor necrosis factor antagonists during pregnancy: a review of the Food and Drug Administration database. J Rheumatol. 2009;36(3):635-641

199. Osting VC, Carter JD. A safety assessment of tumor necrosis factor antagonists during pregnancy. Expert Opin Drug Saf. 2010;9(3): 421-429.

200. Winger EE, Reed JL, Ashoush S, Ahuja S, El-Toukhy T, Taranissi M. Treatment with adalimumab (Humira) and intravenous immunoglobulin improves pregnancy rates in women undergoing IVF. Am J Reprod Immunol. 2009;61(2):113-120.

201. Nadkarni S, Mauri C, Ehrenstein MR. Anti-TNF-alpha therapy induces a distinct regulatory $\mathrm{T}$ cell population in patients with rheumatoid arthritis via TGF-beta. J Exp Med. 2007;204(1):33-39.

202. Clark DA. Should anti-TNF-alpha therapy be offered to patients with infertility and recurrent spontaneous abortion? Am J Reprod Immunol. 2009;61(2):107-112.

203. Clark DA. Anti-TNFalpha therapy in immune-mediated subfertility: state of the art. J Reprod Immunol. 2010;85(1):15-24.

204. Palladino MA, Bahjat FR, Theodorakis EA, Moldawer LL. Anti-TNF-alpha therapies: the next generation. Nat Rev Drug Discov. 2003;2(9):736-746.

205. MacEwan DJ. TNF receptor subtype signalling: differences and cellular consequences. Cell Signal. 2002;14(6):477-492.

206. Calleja-Agius J, Muttukrishna S, Pizzey AR, Jauniaux E. Pro- and antiinflammatory cytokines in threatened miscarriages. Am J Obstet Gynecol. In press. 2011.

International Journal of Interferon, Cytokine and Mediator Research

Dovepress

\section{Publish your work in this journal}

The International Journal of Interferon, Cytokine and Mediator Research is an international, peer-reviewed, open-access, online journal. The focus of the journal is to publish original research, reports, editorials, reviews and commentaries on all aspects of interferon, cytokine and mediators of inflammation from labora- tory science to therapeutic indications and clinical studies. The manuscript management system is completely online and includes a very quick and fair peer-review system, which is all easy to use. Visit http://www.dovepress.com/testimonials.php to read real quotes from published authors. 